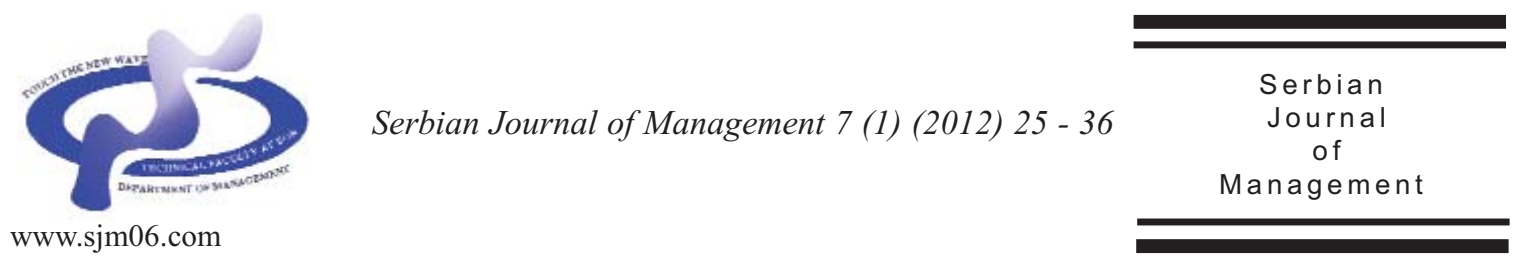

\title{
PERCEIVED VALUE, SERVICE QUALITY, CORPORATE IMAGE AND CUSTOMER LOYALTY: EMPIRICAL ASSESSMENT FROM PAKISTAN
}

\author{
Muhammad Ishtiaq Ishaq ${ }^{a *}$

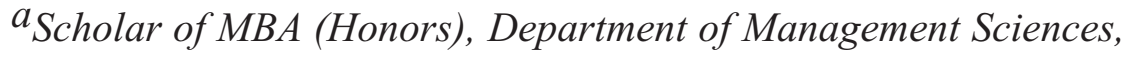 \\ Global Institute Lahore (Pakistan)
}

(Received 12 June 2011; accepted 28 October 2011)

\begin{abstract}
Today's economy is becoming extremely service-oriented, changing the paradigm of marketing research towards services (Carrillat, Jaramillo, \& Mulki 2007). Corporate image, perceived value and service quality have got paramount significance among researchers interested in customer retention strategies. In view of that, this study aimed to determine the antecedents of customer loyalty in telecommunication sector of Pakistan. Data were collected from mobile phones users through questionnaire-based survey and stepwise regression was applied to test the study hypotheses. The study helps the management of telecommunication companies to develop customer oriented strategies. Providing insights regarding relative importance of corporate image, perceived value and service quality for building customer loyalty this research is first of its kind in telecommunication sector of Pakistan.
\end{abstract}

Keywords:Perceived Value, Services Quality, Corporate Image, Customer Loyalty, Telecommunication Sector, Pakistan

\section{INTRODUCTION}

Customer loyalty is considered as the foundation of competitive advantage and has strong influence on company's performance (Rust et al., 2000). Zeithaml et al. (1996) defines customer loyalty as the willingness to stay with current service provider. Loyalty is a purchaser's commitment with service, product, or brand (Oliver, 1999). Customer loyalty is evident itself in variety of the behaviors, "the more common being repeatedly patronizing the service provider and recommending the service provider to other customers" (Lam et al., 2004; Zeithaml et al. 1996). A customer's point of view about value acknowledgement from service provider may motivate him/her to patronize

\footnotetext{
* Corresponding author: ishtiaq_042@yahoo.com
}

DOI: $10.5937 /$ sjm1201025I 
the provider again.

Numerous research studies showed that companies can generate more profit through retaining their current customers rather than to attain previous ones (Hogan et al., 2003, Lee-Kelley et al., 2003). Furthermore, it was observed that loyal customers were less interested in changing the company because of price and they also engaged in positive word-of-mouth communication and refer it to other customers (Reichheld \& Teal, 1996). In 2003, Anderson and Srinivasan claimed that "a dissatisfied customer is more likely to search for information on alternatives and more likely to yield to competitor overtures than is a satisfied customer". These annotations point to the significance of customer loyalty, which provides growth, and continued survival for the companies operating in service sector. Due to high competition in service sector companies often respond by formulating customer retention strategies. (Egan, 2004).

Superior customer loyalty in service industries will lead to better productivity. Several researches had focused on probing the association of customer loyalty with its antecedents (Yi \& Gong, 2008; McMullan \& Gilmore, 2008; Ibanez et al. 2006; Liu et al. 2005; Aydin \& Ozer, 2005; Sirdeshmukh et al. 2002; Cronin et al. 2000). In addition, researchers have also tried to examine the moderation effect of switching costs on the relationship between customer satisfaction and loyalty (Bell et al. 2005; Jones et al. 2000). Besides the antecedent role of customer satisfaction, previous research has also tried to examine relatedness among corporate image, perceived value and service quality and their influence on customer loyalty (Andreassen \& Bodil, 1998; Park et al., 2006).

\section{LITERATURE REVIEW}

Oliver (1999) defined loyalty as "a deeply held commitment to re-buy or repatronize a preferred product/service consistently in the future, thereby causing repetitive samebrand purchasing, despite situational influences and marketing efforts having the potential to cause switching behavior". Loyalty has also been described as "an unspecified number of repeat purchases from the same supplier over a specified period" (Egan, 2004). Numerous researchers have tried to find relevant antecedents and their role in creating customer loyalty. Service quality, customer satisfaction, corporate image, word-of-mouth communication, perceived value have been proposed as antecedents of loyalty (e.g., Wieringa \& Verhoef, 2007; Patterson \& Smith, 2003; Burnham et al., 2003; Jones et al., 2000, 2002, 2007) and these variables are also taken as driving force of competitive advantage and corporate success (Landrum \& Prybutok, 2004; Yang \& Peterson, 2004; Wang, Lo, \& Yang, 2004; Khatibi, Ismail, \& Thyagarajan, 2002; )

Service quality as defined by Parasuraman et al. (1988) results from the comparison of customers' expectations with perceived performance of services. Santos (2003) described service quality as the customers' overall judgment of the excellence of service offering. Service quality is also affected by the ability of an organization to satisfy customers' needs, according to their expectation level (Yoo \& Park, 2007). In current literature of marketing, customer loyalty has got paramount importance and has been recognized as primary instrument to enhance firm's financial performance in today's competitive market. Researchers tried to find 
out the links between loyalty and its key determinants (Guo et al., 2009; Balabanis et al., 2006) whereas service quality has been considered as the key driver of loyalty (Lai et al., 2009). Gruen et al., (2006) found positive association among word-of-mouth communication and customer loyalty. Studies found that emotions in service recovery had positive association with loyalty as well (Lee et al., 2008; Chebat \& Slusarczyk, 2005). Additionally, research also found correlation among service quality and customer satisfaction (Cronin et al., 2000), which in return provides customer loyalty (Lai et al., 2009). Service quality is associated with customers' attitudes towards service supplier and their intent to stay with the service provider (Anton et al. 2007; Bell et al. 2005; Aydin \& Ozer, 2005). Hence, the following is proposed:

Hypothesis 1: Service quality and customer loyalty are positively associated with each other.

Several studies had accepted the crucial part of corporate reputation and corporate image in the customer's buying behavior (Zeithaml, 1981). Corporate reputation and image are considered as important factors in establishing and maintaining loyalty among customers (Raj, 1985). Corporate image is related to customer retention likelihood (Ball et al. 2006; Nguyen \& Leblanc, 2001). According to attitude theory, the foremost cause of corporate image is the evaluation of services which increases value and becomes more accessible in memory (Fazio, 1989). Examining airline services Ostrowski et al. (1993) argue that positive experience over time ultimately leads to positive image. Studies showed the direct impact (Nguyen \& Leblanc, 2001) as well as indirect effect
(Ball et al.2006) of corporate image on customer loyalty. Therefore. the following hypothesis is proposed:

Hypothesis 2: Corporate image is positively related to loyalty.

Customer perceived-value is defined as the perception about quality, social psychology, benefit and money (Bishop, 1984; Velimirović, et al., 2011). Due to its neglectedness in previous studies, several researchers have examined the influence of value on customers' purchase intentions (Lin, Sher, \& Shih, 2005; Eggert \& Ulaga, 2002; Petrick, 2002). Previous studies have pointed to the positive relationship among service quality and perceived value (Bauer et al., 2006) which has been shown to cause loyalty among the customers. In telecommunication sector, Turel and Serenko (2006) and Wang et al. (2004) studied mobile services in Canada and China respectively and found positive relationship between them. Similarly, researches proved the positive relationship in most cases between these two variables (Hsu, 2006; Eggert \& Ulaga, 2002). In telecommunication sector, Lin and Wang (2006) and Tung (2004) found positive relationship among perceived value and customer satisfaction. Many research scholars also found direct relationship of perceived value with word-of-mouth communication and repurchase intentions (Lin et al., 2005, Cronin et al. 2000). Wang et al. (2004) and Lin and Wang (2006) also supported this result. There is also positive association found between consumerperceived value and customer loyalty (Yang \& Peterson, 2004; Sirdeshmukh et al. 2002).

Hypothesis 3: The greater the perceived value, the higher the customer loyalty. 
The conceptual model of this research is as presented in Figure 1.

\section{RESEARCH DESIGN}

Convenience sampling was used to assess opinions of five cellular companies' customers regarding perceived value, service quality, and corporate image. The respondents of this study were employees working in different national and multinational companies in the field of FMCG, textile, home appliances, chemical etc. The reasons for choosing convenience sampling technique was that the data of the informants are not available publically and also this study was conducted to improve understanding about the antecedents of customer loyalty in telecommunication industry of Pakistan. Five hundred questionnaires were sent to the respondents and 357 questionnaires were returned and only 340 questionnaires were usable (response rate $=68 \%$ ) for statistical analysis. Customer loyalty was measured on a fiveitem scale of Lam et al. (2004). Ten items were used to measure service quality. Perceived value was measured by two items drawn from Cronin et al. (2000). Corporate image was measured by five measures taken from Souiden et al. (2006). Stepwise regression analysis was used to analyze the hypotheses of this research. Service quality, corporate image, and perceived value were considered as independent variables and customer loyalty as dependent variable. Factor analysis was used for data purification before variables were entered into the regression model. Due to the factor loadings ranging from $0.70-0.84$ (see appendix), all the items were retained. Demographic profile is shown in Table 1.

\section{RESULTS}

Reliability coefficients and descriptive statistics are presented in Table 2. The reliability coefficients were above 0.6 which is in line with the recommended threshold (Bagozzi \& Yi, 1988). Correlations among the constructs are presented in Table 3.

Stepwise regression analysis was used to determine the impact of three independent variables named corporate image, perceived value and service quality on customer loyalty, as presented in Table 4. The table showed that 60 percent variance in customer loyalty was accounted for by the model containing service quality and customer perceived value which is significant at 0.001 level whereas the third independent variable (corporate image) was excluded from the model because of its non-significance in

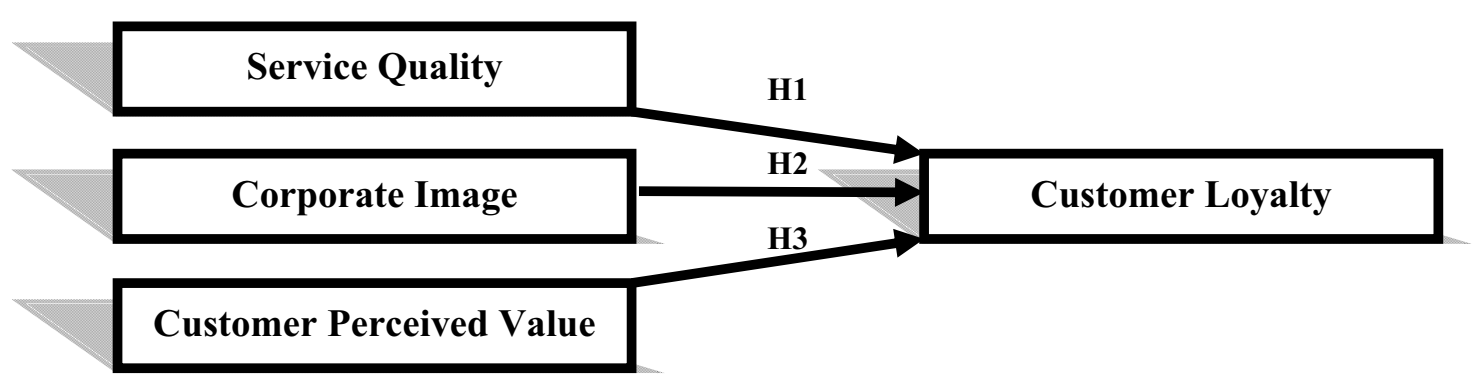

Figure 1. Conceptual Model of Research 
Table 1. Demographics Profile of Investigated Population $(N=340)$

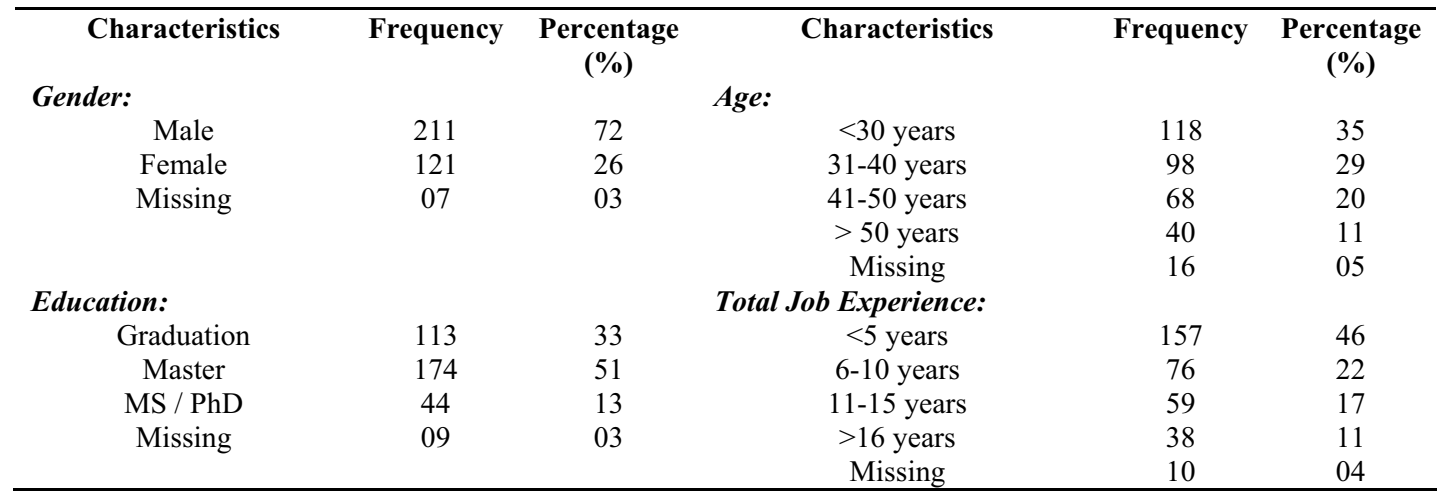

model. These findings were found to be consistent with the research hypotheses that customer perceived value and service quality are positively related to customer loyalty.

Standardized beta coefficients (Table 5) show the relative impact of service quality and customer perceived value on customer loyalty. It was found that service quality $(b=$ $.37, \mathrm{t}=9.3, \mathrm{p}<0.001$ ) had stronger influence on customer loyalty than customer perceived value $(\mathrm{b}=.15, \mathrm{t}=3.09, \mathrm{p}<0.001)$ whereas corporate image was excluded from the model.

\section{CONCLUSIONS}

The purpose of this research is to ascertain the impact of customer perceived value, service quality and corporate image on customer loyalty. The results showed that corporate image has no influence in promoting customer loyalty in telecommunication industry of Pakistan whereas service quality got high importance by the customers. Kim et al. (2004) conducted a research on Korean customers and found that service quality, brand image and switching costs perceptions were the main determinants of customer loyalty.

Table 2. Descriptive Statistics and Reliability Coefficients

\begin{tabular}{lccc}
\hline \multicolumn{1}{c}{ Variables } & Reliability & Mean & Std. Deviation \\
Service quality & $\alpha=0.91$ & 3.42 & 0.68 \\
Customer-perceived Value & $\alpha=0.87$ & 3.55 & 0.87 \\
Customer Loyalty & $\alpha=0.91$ & 3.37 & 0.76 \\
Corporate Image & $\alpha=0.91$ & 3.60 & 0.79 \\
\hline
\end{tabular}

Table 3. Correlation Matrix $(N=340)$

\begin{tabular}{llrrrr}
\hline & & $\begin{array}{c}\text { Service } \\
\text { Quality }\end{array}$ & $\begin{array}{l}\text { Customer } \\
\text { Perceived } \\
\text { Value }\end{array}$ & $\begin{array}{c}\text { Customer } \\
\text { Loyalty }\end{array}$ & $\begin{array}{c}\text { Corporate } \\
\text { Image }\end{array}$ \\
Pearson & Service Quality & 1.00 & $.39^{*}$ & $.44^{*}$ & $.37^{*}$ \\
Correlation & Customer Perceived Value & $.39^{*}$ & 1.00 & $.58^{*}$ & $.61^{*}$ \\
& Customer Loyalty & $.44^{*}$ & $.58^{*}$ & 1.00 & $.70^{*}$ \\
& Corporate Image & $.37^{*}$ & $.61^{*}$ & $.70^{*}$ & 1.00 \\
\hline
\end{tabular}

* Significant at 0.001 level 
Table 4. Parameters of Stepwise Regression Analysis Model

\begin{tabular}{|c|c|c|c|c|c|c|c|c|c|c|}
\hline \multicolumn{11}{|c|}{ Model Summary(Dependent Variable: Customer Loyalty) } \\
\hline \multirow{2}{*}{ Model } & \multirow[t]{2}{*}{$\mathbf{R}$} & \multirow{2}{*}{$\mathbf{R}^{2}$} & \multirow{2}{*}{$\begin{array}{c}\text { Adjusted } \\
\mathbf{R}^{2}\end{array}$} & \multirow{2}{*}{$\begin{array}{l}\text { Std. Error } \\
\text { of the } \\
\text { Estimate }\end{array}$} & \multirow[b]{2}{*}{$\begin{array}{c}\mathbf{R}^{2} \\
\text { Change }\end{array}$} & \multicolumn{3}{|c|}{ Change Statistics } & \multirow[b]{2}{*}{$\begin{array}{l}\text { Sig. F } \\
\text { Change }\end{array}$} & \multirow{2}{*}{$\begin{array}{l}\text { Durbin- } \\
\text { Watson }\end{array}$} \\
\hline & & & & & & $\begin{array}{c}\text { F } \\
\text { Change }\end{array}$ & df1 & df2 & & \\
\hline 1 & $.52^{\mathrm{a}}$ & .51 & .50 & .84 & .51 & 25.84 & 1 & 179 & .000 & \\
\hline 2 & $.61^{\mathrm{b}}$ & .60 & .60 & .83 & .10 & 4.92 & 1 & 178 & .000 & 1.87 \\
\hline
\end{tabular}

a. predictors: (constant), service quality, b. predictors: (constant), service quality and customer perceived value; * Significant at 0.001 level

Table 5. Model Coefficients ${ }^{a}$

\begin{tabular}{|c|c|c|c|c|c|c|c|}
\hline \multirow[t]{2}{*}{ Model } & \multicolumn{2}{|c|}{$\begin{array}{l}\text { Unstandardized } \\
\text { Coefficients }\end{array}$} & \multirow{3}{*}{$\begin{array}{l}\text { Standardized } \\
\text { Coefficients } \\
\text { Beta }\end{array}$} & & \multirow[t]{2}{*}{ Sig. } & \multicolumn{2}{|c|}{ Collinearity Statistics } \\
\hline & B & Std. Error & & & & Tolerance & VIF \\
\hline (Constant) & 2.92 & .12 & & 25.13 & .000 & & \\
\hline Service quality & .38 & .04 & .37 & 9.30 & .000 & .69 & 1.43 \\
\hline $\begin{array}{l}\text { Customer-perceived Value } \\
\text { a. Dependent Variable: } \text { customer }\end{array}$ & .19 & .03 & .15 & 3.09 & .002 & .56 & 1.79 \\
\hline
\end{tabular}

Similarly Lee et al. (2001) also found the strong effect of switching costs on satisfaction $\rightarrow$ loyalty among French mobile service users. In United States of America, low price, corporate image and consistent quality affect the customer loyalty. Aydin and Ozer (2005) found positive relationship between service quality and loyalty among Turkish mobile phone users. In general, the customers belong to Asian culture focuses on less tangible characteristics of service as significant aspect (Mattila, 1999). In Pakistan, marketers faced numerous challenges to satisfy the customers while implementing western based theories because of rapid changes in growth, social transitions and culture.

These results had implication for practice and theory. For theory perspective, the study findings demonstrate that there is a need to incorporate constructs other than service quality, corporate image, and perceived value for customer loyalty in order to extend current theories of customers' behavioral responses (Ball et al. 2006; Nguyen \&
Leblanc, 2001). Seiders et al. (2005) also concluded that relational, marketplace and customer characteristics moderate the relationship between satisfactions and repurchase behavior.

This research has some limitations and recommendations for future research. First, this research was limited to one sector (telecommunications). Thus, it would be valuable to replicate the study in other service industries, e.g., health care, fast-food, insurance, including service quality dimensions. Second, future research may apply the model of this survey in an experimental setting utilizing scenarios to manipulate key constructs. Finally, the crosssectional design was used so to get initial understanding about the causal relationship. Therefore, longitudinal studies should be conducted for gaining deeper insights into cause-effect relationships. 


\title{
ОСТВАРЕНА ВРЕДНОСТ, КВАЛИТЕТ УСЛУГЕ, КОРПОРАТИВНИ ИМИЏ И ЛОЈАЛНОСТ КУПАЦА: ЕМПРИСИЈСКА ИСТРАЖИВАЫА ИЗ ПАКИСТАНА
}

\author{
Muhammad Ishtiaq Ishaq ${ }^{\mathrm{a} *}$ \\ ${ }^{a}$ Scholar of MBA (Honors), Department of Management Sciences, \\ Global Institute Lahore (Pakistan)
}

\section{Извод}

Модерна економија је екстремно сервисно оријентисана, померајући парадигму маркетиншких истраживања ка услугама (Carrillat, Jaramillo, \& Mulki 2007). Корпоративни имиџ, остварена вредност и квалитет услуга добија огромни значај међу истраживачима који се баве стратегијом освајања поверења купаца. У том смислу, ово истраживање има за циљ да одреди полазне услове за задовољство купаца у телекомуникационом сектору пакистана. Подаци су сакупљени од корисника мобилних телефона преко анкетних листова. Поттом је примењена "stepwise" регресиона анализа у циљу тестирања полазних хипотеза. Ова студија може помоћи менаџменту телекомуникцаионих компанија у развоју стратегија оријентисаних ка купцу. Добијање увида у значај корпоративног имиџа, остварене вредности и квалитета услуга за изградњу лојалности купаца, ово је истраживање прво ове врсте у телекомуникационом сектору Пакистана.

Кључне речи: Остварена вредност, Квалитет услуга, Корпоративни имиџ, Лојалност купаца, телекоминикације, Пакистан

\section{References}

Anderson, R.E. and Srinivasan, S.S. (2003) E-satisfaction and e-loyalty: a contingency framework. Psychology and Marketing, 20 (2): 123-38.

Andreassen, T.W., Lindestad, B. (1998) Customer loyalty and complex Services: The impact of corporate image on quality, customer satisfaction and loyalty for customers with varying degrees of service expertise, International Journal of Service Industry Management, 9(1): 7-23

Anton, C., Camarero, C., \& Carrero, M. (2007) The mediating effect of satisfaction on consumers' switching intention. Psychology \& Marketing, 24: 511-538.
Aydin, S., \& Ozer, G. (2005) The analysis of antecedents of customer loyalty in the Turkish mobile telecommunication market. European Journal of Marketing, 39: 910-925.

Balabanis, G., Reynolds, N., \& Simintiras, A. (2006) Bases of e-store loyalty: Perceived switching barriers and satisfaction. Journal of Business Research, 59(2): 214-224.

Ball, D., Coelho, P. S., \& Vilares, M. J. (2006) Service personalization and loyalty. Journal of Services Marketing, 20: 391-403.

Barich, H., \& Kotler, P. (1991) A framework for marketing image management. Sloan Management Review, 32: 94-104. 
Bauer, H. H., Falk, T., \& 76:193-218.

Hammerschmidt, M. (2006) eTransQual: A transaction process-based approach for capturing service quality in online shopping. Journal of Business Research, 59(7): 866-875.

Bell, S. J., Auh, S., \& Smalley, K. (2005) Customer relationship dynamics: Service quality and customer loyalty in the context of varying levels of customer expertise and switching costs. Journal of the Academy of Marketing Science, 33:169-183.

Bishop, W. R. Jr., (1984) Competitive intelligence. Progressive Grocer, 63(3): 19-20.

Boloemer, J., \& Ruyter, Ko de (1998) On the relationship between store image, store satisfaction and store loyalty. European Journal of Marketing, 32: 499-513.

Bolton, R.N., \& Drew, J.H. (1991) A multistage model of customer's assessments of service quality and value. Journal of Consumer Research, 17: 375-384.

Burnham T.A., Frels J.K., \& Mahajan V. (2003) Consumer switching costs: a typology, antecedents, and consequences. $\mathrm{J}$ Acad Mark Sci, 31(2):109-27.

Burnham,T. A., Frels, J. K., \& Mahajan,V. (2003) Consumer switching costs: A typology, antecedents, and consequences. Journal of the Academy of Marketing Science, 31: 109-126.

Chebat, J.C., \& Slusarczyk, W. (2005) How emotions mediate the effects of perceived justice on loyalty in service recovery situations: an empirical study. Journal of Business Research, 58(5): 664673.

Cronin, J. J., Jr., Brady, M. K., \& Hult,G.T. M. (2000) Assessing the effects of quality, value, and customer satisfaction on consumer behavioral intentions in service environments. Journal of Retailing,
Dick, A. S., \& Basu, K. (1994) Customer loyalty:Toward an integrated conceptual framework. Journal of the Academy of Marketing Science, 22: 99-114.

Egan, J. (2004) Relationship Marketing: Exploring Relational Strategies in Marketing, Pearson Education, Harlow.

Eggert, A., \& Ulaga, W. (2002) Customer perceived value: A substitute for satisfaction in business markets. The Journal of Business and Industrial Marketing, 17(2/3): 107-118.

Fazio R. (1989) On the power and functionality of attitudes: the role of attitude accessibility. Attitude, structure and function. Hillside: Erlbaum.

Gerpott T.J, Rams, W., Schindler, A. (2001) Customer retention, loyalty, and satisfaction in the German mobile cellular telecommunications market. Telecommun Policy, 25 (4):249-69.

Gruen, T.W., Osmonbekov, T., \& Czaplewski, A.J. (2006) eWOM: The impact of customer-to-customer online know-how exchange on customer value and loyalty. Journal of Business Research, 59(4): 449456.

Guo, L., Xiao. J.J., Tang, C. (2009) Understanding the psychological process underlying customer satisfaction and retention in a relational service. Journal of Business Research, 62(11): 1152-1159.

Hauser, J. R., \& Wernerfelt, B. (1990) Relational benefits in services industries. Journal of Consumer Research, 16:393-408.

Heide, J. B., \& Weiss, A.M. (1995) Vender consideration and switching behavior for buyers in high-technology markets. Journal of Marketing, 59: 30-43.

Heskett, J. L., Jones,T.O., Loveman,G.W., Sasser, E.W., \& Schlesinger, L. (1994) Putting the service-profit chain to work. Harvard Business Review, 72: 164-174. 
Hogan, J.E., Katherine, N.L. and Barak, L. (2003) What is the true value of a lost customer? Journal of Service Research, 5 (3): 196-208.

Hsu, H. (2006) An empirical study of web site quality, customer value, and customer satisfaction based on e-shop. The Business Review, 5(1):190-193.

Ibanez,V. A., Hartmann, P.,\& Calvo, P. Z. (2006) Antecedents of customer loyalty in residential energy markets: Service quality, satisfaction, trust and switching costs. Service Industries Journal, 26:633-650.

Jackson, B. B. (1985) Winning and keeping industrial customers: The dynamics of customer relationship. Lexington, MA: Lexington Books.

Jones M.A., Mothersbaugh, D.L., \& Beatty, S.E. (2000) Switching barriers and repurchase intentions in services. J Retailing, 76(2):259-74.

Jones M.A., Mothersbaugh, D.L., \& Beatty, S.E. (2002) Why customers stay: measuring the underlying dimensions of services switching costs and managing their differential strategic outcomes. J Bus Res, 55(6):441-50.

Jones M.A., Mothersbaugh, D.L., \& Beatty, S.E. (2007) The positive and negative effects of switching costs on relational outcomes. J Serv Res, 9(4):335-55.

Jones,M. A., Mothersbaugh, D. L., \& Beatty, S. E. (2000) Switching barriers and repurchase intentions in services. Journal of Retailing, 76: 259-274.

Khatibi, A. A., Ismail, H., \& Thyagarajan, V. (2002) What drives customer loyalty: An analysis from the telecommunications industry. Journal of Targeting, Measurement and Analysis for Marketing, 11(1): 34-44.
Lai, F., Griffin, M., \& Babin, B.J. (2009)

How quality, value, image, and satisfaction create loyalty at a Chinese telecom. Journal of Business Research, 62(10): 980-986.

Lam, S. Y., Shankar, V., Erramilli, M. K., \& Murthy, B. (2004) Customer value, satisfaction, loyalty, and switching costs: An illustration from a business-to-business service context. Journal of the Academy of Marketing Science, 32:293-311.

Landrum, H., \& Prybutok, V. R. (2004) A service quality and success model for the information service industry. European Journal of Operational Research, 156(3): 628-642.

Lee J., Lee, J., Feick, L. (2001) The impact of switching costs on the customer satisfaction-loyalty link: mobile phone service in France. J Serv Mark, 15(1):35-48.

Lee, Y.K., Lee, C.K., Lee, S.K., \& Babin, B.J. (2008) Festival scapes and patrons' emotions, satisfaction, and loyalty. Journal of Business Research, 61(1): 56-64.

Lee-Kelley, L., Gilbert, D. and Mannicom, R. (2003) How e-CRM can enhance customer loyalty. Marketing Intelligence \& Planning, 21(4): 239-48.

Lin, C. H., Sher, P. J., \& Shih, H. Y. (2005) Past progress and future directions in conceptualizing customer perceived value. International Journal of Service Industry Management, 16(3/4): 318-336.

Lin, H. H., \& Wang, Y. S. (2006) An examination of the determinants of customer loyalty in mobile commerce contexts. Information and Management, 43(3): 271-282.

Liu, A. H., Leach, M. P., \& Bernhardt, K. L. (2005) Examining customer value perceptions of organizational buyers when sourcing from multiple vendors. Journal of 
Business Research, 58: 559-568.

Mattila A.S. (1999) The role of culture in the service evaluation process. J Serv Res, 1(3):250-61.

McMullan, R., \& Gilmore, A. (2008) Customer loyalty: An empirical study. European Journal of Marketing, 42:1084-1094.

Nguyen, N., \& Leblanc, G. (2001) Corporate image and corporate reputation in consumers' retention decisions in services. Journal of Retailing and Consumer Services, 8: 227-236.

Oliva, T. A., Oliver, R. L., \& MacMillan, I. C. (1992) A catastrophe model for developing service satisfaction strategies. Journal of Marketing, 56:83-95.

Oliver, R. L. (1999). Whence customer loyalty? Journal of Marketing, 63:33-44.

Parasuraman, A., Zeithaml, V. A., \& Berry, L. L. (1988) SERVQUAL: A multipleitem scale for measuring consumer perceptions of service quality. Journal of Retailing, 64:12-40.

Park, J.W., Robertson, R., Wu, C.L. (2006) Modelling the Impact of Airline Service Quality and Marketing Variables on Passengers' Future Behavioural Intentions, Transportation Planning and Technology, 29(5): 359-381

Patterson P.G., \& Smith T. (2003) A crosscultural study of switching barriers and propensity to stay with service providers. J Retailing, 79(2):107-20.

Petrick, J. F. (2002) Development of a multi-dimensional scale for measuring the perceived value of a service. Journal of Leisure Research, 34(2): 119-134.

Reichheld, F.F. and Teal, T. (1996) The Loyalty Effect: The Hidden Force Behind Growth, Profits, and Lasting Value, Bain \& Company, Boston, MA.

Rust, Zeithaml, V., and Lemon, K., (2000)
Driving Customer Equity. Boston: Free Press.

Santos, J. (2003) E-Service Quality: A Model of Virtual Service Quality Dimensions. Managing Service Quality, 13(3): 233-46.

Seiders, K., Voss, G. B., Grewal, D., \& Godfrey, A. L. (2005) Do satisfied customers buy more? Examining moderating influences in a retailing context. Journal of Marketing, 69:26-43.

Sirdeshmukh, D., Singh, J.,\& Sabol, B. (2002) Customer trust, value, and loyalty in relational exchanges. Journal of Marketing, 66:15-37.

Souiden,N., Kassim,N. M., \& Hong, H.-J. (2006) The effect of corporate branding dimensions on consumers' product evaluation. European Journal of Marketing, 40:825-845.

Tsai, H.-T., Huang, H.-C., Jaw, Y.-L., \& Chen,W.-K. (2006) Why online customers remain with a particular e-retailer: An integrative model and empirical evidence. Psychology \& Marketing, 23:447-464.

Tung, L. L. (2004) Service quality and perceived value's impact on satisfaction, intention and usage of short message service (SMS). Information Systems Frontiers, 6(4): 353-368.

Turel, O., \& Serenko, A. (2006) Satisfaction with mobile services in Canada: An empirical investigation. Telecommunications Policy, 30(5/6): 314-331.

Velimirović, D., Velimirović, M., \& Stanković, R. (2011) Role and importance of key performance indicators measurement. Serbian Journal of Management, 6(1): 63-72.

Wang, Y., Lo, H. P., \& Yang, Y. (2004) An integrated framework for service quality, customer value, satisfaction: Evidence from China's telecommunication industry. 
Information Systems Frontiers, 6(4): 325-340.

Wieringa, J.E., \& Verhoef, P.C. (2007) Understanding customer switching behavior in a liberalizing service market. J Serv Res,10(2):174-86.

Woodruff, R. B. (1997) Customer value: The next source for competitive advantage. Journal of the Academy of Marketing Science, 25: 139-153.

Yi, Y., \& Gong, T. (2008) The electronic service quality model: The moderating effect of customer self-efficacy. Psychology \& Marketing, 25:587-601.

Yoo, D.K., Park, J.A. (2007) Perceived service quality - analyzing relationships among employees, customers, and financial performance, International Journal of Quality \& Reliability Management, 24 (9):908-26.

Z., \& Peterson, R.T. (2004) Customer perceived value, satisfaction, and loyalty: The role of switching costs. Psychology \& Marketing, 21:799-822.

Zeithaml, V. A., Berry, L. L., \& Parasuraman, A. (1996) The behavioral consequences of service quality. Journal of Marketing, 60: 31-46. 


\section{APPENDIX I: Questionnaire with factor loading}

\begin{tabular}{llr}
\hline Constrict Name & Items & Factor Loading \\
& $\begin{array}{l}\text { Generally, the employees of the company provide service } \\
\text { reliably, consistently, and dependably. }\end{array}$ & 0.72 \\
& $\begin{array}{l}\text { Generally, the employees of the company are willing and } \\
\text { able to provide service in a timely manner. }\end{array}$ & 0.77 \\
& $\begin{array}{l}\text { Generally, the employees of the company are competent } \\
\text { (i.e., knowledgeable and skillful). }\end{array}$ & 0.71 \\
& $\begin{array}{l}\text { Generally, the employees of the company are } \\
\text { approachable and easy to contact. }\end{array}$ & 0.73 \\
SERVICE & $\begin{array}{l}\text { Generally, the employees of the company are courteous, } \\
\text { polite, and respectful. }\end{array}$ & 0.70 \\
QUALITY & $\begin{array}{l}\text { Generally, the employees of the company listen to me and } \\
\text { speak in a language that I can understand. }\end{array}$ & 0.81 \\
& $\begin{array}{l}\text { Generally, the employees of the company are trustworthy, } \\
\text { believable, and honest. }\end{array}$ & 0.71 \\
Generally, the company provides an environment that is \\
free from danger, risk, or doubt.
\end{tabular}

